\title{
Theoretical Evaluation of Potential Anti-Alanine Dehydrogenase Activities of Acetamide Derivatives
}

\author{
Moriam Dasola Adeoye ${ }^{1(\mathbb{D})}$, Elizabeth Funke Olarinoye ${ }^{2}{ }^{(\mathbb{D})}$, Abel Kolawole Oyebamiji ${ }^{3, *}{ }^{\mathbb{C}}$, Dayo Felix \\ Latona $^{2}$ iD \\ 1 Department of Chemical Sciences, Fountain University, Osogbo, Nigeria; dasoladeoye@ yahoo.com (M.D.A.); \\ 2 Department of Pure and Applied Chemistry, Osun State University, Osogbo, Nigeria; dayo.latona@uniosun.edu.ng \\ (D.F.L.); \\ 3 Department of Basic Sciences, Adeleke University, PMB 250, Ede, Osun State, Nigeria; abeloyebamiji@gmail.com \\ (A.K.O.); \\ * Correspondence: abeloyebamiji @gmail.com (A.K.O.);
}

Scopus Author ID: 57189714998

Received: 5.10.2021; Revised: 2.11.2021; Accepted: 5.11.2021; Published: 25.11.2021

\begin{abstract}
Tuberculosis is an airborne communicable syndrome, which has been observed to be among the top ten (10) causes of death worldwide. This work studied eleven molecular compounds via quantum chemical calculations, molecular docking method, and ADMET (absorption, distribution, metabolism, excretion, and toxicity). The selected obtained descriptors (Log P, HBA, HBD, and molecular weight) showed that the studied compounds have the ability to act drug-like. Compound $\mathbf{D}$ inhibited far better than the other studied ligands as well as the standard. ADMET properties of compound $\mathbf{D}$ proved that the predicted ADMET level was closer to the ADMET properties of the referenced drug (Isoniazid).
\end{abstract}

Keywords: 2-(quinoline-4-yloxy)acetamide; tuberculosis; QSAR; DFT; docking; ADMET.

(C) 2021 by the authors. This article is an open-access article distributed under the terms and conditions of the Creative Commons Attribution (CC BY) license (https://creativecommons.org/licenses/by/4.0/).

\section{Introduction}

M. tuberculosis remains one of the dangerous diseases among human beings. Despite the continuous effort put in place by several researchers to combat this disease, the rate of killing human beings remains high. According to the report by Law et al., 2019 [1], the call for more and effective anti-tubercular drugs has increased despite several anti-tubercular drugs circulating globally. In 2019, more than 1 million tuberculosis-based death cases were reported by the world health organization (WHO), and the resistance of some of its strains to drugs remains a difficult issue in the medical world [2]. According to Kenia et al., 2016, less than half of the world's population has either latent or dormant type of tuberculosis [3].

Series of heterocyclic compounds have been observed to possess antimicrobial activities, and some of the compounds have been found to be located in natural and synthetic molecules with therapeutic values [4]. Heterocyclic ring systems are contained in many dye compounds, drug-like compounds, and several natural molecules like hormones, amino acids, and alkaloids. Many heterocyclic molecular compounds such as pyrimidines, thiazole, piperidine, pyridine, furan, pyrrolidine, and thiophene reveal substantial biological activities. According to several researchers, quinoline-based drug-like compounds have been reported to have great attention by scientists due it pharmacological importance such as antimicrobial, antiinflammatory, antimalarial, anticancer, antiviral, and antifungal activities [5]. 
The role played by the quantum chemical method in the scientific sphere cannot be overemphasized. It helps in sustainability, determination of chemical structure, and elucidation of molecular reactivity [6]. Also, density functional theory remains a vital instrument for making a novel series of reasons vindicating calculations in several parts of chemical methods [6-10], and due to its level of accuracy, it has drawn the attention of many researchers globally [11].

Molecular docking study is an emerging imperative technique used for drug development, and it remains the main tool in computer-based drug design [11]. Docking acts as a screening tool in drug discovery to identify compounds with better inhibiting affinity. It also exposes the ligand pose in the receptor's active site, which is imperative for optimization [12-15].

In this work, eleven molecular compounds were studied to identify the descriptors responsible for its anti-tubercular activities and development of a reliable quantitative structure-activity relationship (QSAR) model for better prediction of the experimental inhibition concentration $\left(\mathrm{IC}_{50}\right)$ as well as observing the interactions between the acetamide derivatives and Alanine Dehydrogenase (PDB ID: 2voe).

\section{Materials and Methods}

\subsection{Optimization of the studied compounds.}

Eleven molecular compounds synthesized by Ana et al., 2020 were optimized using quantum chemical calculations [16] via Spartan 14 software [17-25] which brought about electronic descriptors (Highest occupied molecular orbital energy, lowest unoccupied molecular orbital energy, band gap, dipole moment, log P, ovality, polarizability, hydrogen bond donor and hydrogen bond acceptor) that describe anti-tubercular activities of 2(quinoline-4-yloxy) acetamide derivatives. The studied alkaloids were 2-((6-Methoxy-2methylquinolin-4-yl)oxy)-1-phenylethan-1-one (A), 2-((6-Methoxy-2-methylquinolin-4yl)oxy)-1-(4-methoxyphenyl)ethan-1-one (B), 2-((6-Methoxy-2-methylquinolin-4-yl)oxy)-1(3-methoxyphenyl)ethan-1-one (C), 2-((6-Methoxy-2-methylquinolin-4-yl)oxy)-1-(2methoxyphenyl)ethan-1-one (D), 2-((6-Methoxy-2-methylquinolin-4-yl)oxy)-1-(ptolyl)ethan-1-one (E), 1-(4-Fluorophenyl)-2-((6-methoxy-2-methylquinolin-4-yl)oxy)ethan-1one (F), 1-(4-Chlorophenyl)-2-((6-methoxy-2-methylquinolin-4-yl)oxy)ethan-1-one (G), 1-(3Chlorophenyl)-2-((6-methoxy-2-methylquinolin-4-yl)oxy)ethan-1-one $\quad(\mathbf{H}), \quad$ 1-(3,4Dichlorophenyl)-2-((6-methoxy-2-methylquinolin-4-yl)oxy)ethan-1-one (I), 1-(4Isobutylphenyl)-2-((6-methoxy-2-methylquinolin-4-yl)oxy)ethan-1-one (J), 2-((6-Methoxy-2methylquinolin-4-yl)oxy)-1-phenylpropan-1-one (K) (Table 1).

\subsection{Docking study.}

The molecular interactions between 2-(quinoline-4-yloxy)acetamide derivatives and alanine dehydrogenase (PDB ID: 2voe) were investigated using a docking study. Alanine dehydrogenase (PDB ID: 2voe) was obtained from a protein data bank (www.rcsb.org) before further processing. A series of molecular docking software was employed to observe the residues involved in the interaction and the types of interactions between the studied complexes. The software used were PyMOL, Autodock tool 1.5.6, Autodock vina, and Discovery studio. The observed values which showed the employed active site in the receptor 
were as follows: center $(X=23.867, Y=-0.595, Z=63.69)$ and size $(X=56, Y=68, Z=62)$; as well as the spacing for individual receptor was set at $1.00 \AA$.

\subsection{Studied ADMET properties.}

Absorption, distribution, metabolism, excretion, and toxicity (ADMET) of the selected compounds with the highest binding affinity and the referenced drug used were examined using online software (admetSAR) [26]. The considered ADMET factors were Blood-Brain Barrier, Human Intestinal Absorption, Caco-2 Permeability, P-glycoprotein Substrate, P-glycoprotein Inhibitor, Renal Organic Cation Transporter, Subcellular localization, CYP450 2C9 Substrate, CYP450 2D6 Substrate, CYP450 3A4 Substrate, CYP450 1A2 Inhibitor, CYP450 2C9 Inhibitor, CYP450 2D6 Inhibitor, CYP450 2C19 Inhibitor, CYP450 3A4 Inhibitor, CYP Inhibitory Promiscuity, Human Ether-a-go-go-Related Gene Inhibition, AMES Toxicity, Carcinogens, Fish Toxicity, Tetrahymena Pyriformis Toxicity, Honey Bee Toxicity, Biodegradation.

Table 1. 2D structure of the studied compounds.

\begin{tabular}{|c|c|c|}
\hline & $\mathrm{R}^{1}$ & $\mathrm{R}^{2}$ \\
\hline $\mathrm{A}$ & $\mathrm{H}$ & $\mathrm{Ph}$ \\
\hline B & $\mathrm{H}$ & 4-MeO-Ph \\
\hline $\mathrm{C}$ & $\mathrm{H}$ & 3-MeO-Ph \\
\hline $\mathrm{D}$ & $\mathrm{H}$ & 2-MeO-Ph \\
\hline$E$ & $\mathrm{H}$ & 4-Me-Ph \\
\hline $\mathrm{F}$ & $\mathrm{H}$ & 4-F-Ph \\
\hline $\mathrm{G}$ & $\mathrm{H}$ & 4-Cl-Ph \\
\hline $\mathrm{H}$ & $\mathrm{H}$ & 3-Cl-Ph \\
\hline I & $\mathrm{H}$ & $3,4-(\mathrm{Cl})_{2}-\mathrm{Ph}$ \\
\hline $\mathrm{J}$ & $\mathrm{H}$ & 4-i-Bu-Ph \\
\hline $\mathrm{K}$ & $\mathrm{Me}$ & $\mathrm{Ph}$ \\
\hline
\end{tabular}

\section{Results and Discussion}

\subsection{Calculated descriptors from optimized 2-(quinoline-4-yloxy)acetamide derivatives.}

Calculated molecular descriptors for 2-(quinoline-4-yloxy)acetamide derivatives used to investigate their anti-tubercular activities were molecular weight, hydrophobicity ( $\log \mathrm{P})$, volume (V), Area, polar surface area (PSA), ovality, dipole moment (DM), Highest occupied molecular Orbital ( $\mathrm{E}_{\text {HOMO }}$ ), and Lowest unoccupied molecular orbital ( $\mathrm{E}_{\mathrm{LUMO}}$ ) energies as shown in Tables 2. The calculated descriptors were subjected to Lipinski rule of five (Molecular Weight $\leq 500, \mathrm{HBD} \leq 5, \mathrm{HBA} \leq 10$ and $\log \mathrm{P} \leq 5$ ) [27], so to examine the druglikeness ability of the studied compounds, and it was observed that all the studied compounds conformed well with the Lipinski rule of five which is a proof that all the compounds under study potential ability to act as a drug against $M$. tuberculosis. The calculated molecular weight, HBD, HBA and Log P for compound A-K were $307.349 \mathrm{amu}, 337.375 \mathrm{amu}, 337.375 \mathrm{amu}$, $337.375 \mathrm{amu}, 321.376 \mathrm{amu}, 325.339 \mathrm{amu}, 341.794 \mathrm{amu}, 341.794 \mathrm{amu}, 376.239 \mathrm{amu}, 363.457$ 
amu and 321.376; 0, 0, 0, 0, 0, 0, 0, 0, 0, 0, 0; 4, 5, 5, 5, 4, 4, 4, 4, 4, 4, 4 and 0.18, 0.05, 0.05, $0.05,0.66,0.33,0.73,0.73,1.29,1.83,0.67$ (Table 2).

Table 2. Selected molecular descriptors obtained using B3LYP/6-31+G*.

\begin{tabular}{|c|c|c|c|c|c|c|c|c|c|c|}
\hline & $\begin{array}{c}\text { Еномо } \\
(\mathrm{eV})\end{array}$ & $\begin{array}{c}\text { ELUMo }_{\text {LUM }} \\
(\mathrm{eV})\end{array}$ & $\begin{array}{l}\text { BG } \\
(\mathrm{eV})\end{array}$ & $\begin{array}{c}\text { DM } \\
\text { (Debye) }\end{array}$ & $\begin{array}{c}\text { MW } \\
\text { (amu) }\end{array}$ & $\log P$ & $\operatorname{Vol}\left(\AA^{3}\right)$ & Ovality & HBD & HBA \\
\hline $\mathbf{A}$ & -8.61 & -0.88 & 7.73 & 5.75 & 307.349 & 0.18 & 323.07 & 1.49 & 0 & 4 \\
\hline B & -8.11 & -0.67 & 7.44 & 3.31 & 337.375 & 0.05 & 346.29 & 1.51 & 0 & 5 \\
\hline $\mathrm{C}$ & -8.33 & -0.91 & 7.42 & 8.45 & 337.375 & 0.05 & 350.78 & 1.54 & 0 & 5 \\
\hline D & -8.24 & -0.84 & 7.4 & 9.13 & 337.375 & 0.05 & 349.68 & 1.53 & 0 & 5 \\
\hline $\mathbf{E}$ & -8.31 & -0.81 & 7.5 & 7.99 & 321.376 & 0.66 & 341.19 & 1.52 & 0 & 4 \\
\hline $\mathbf{F}$ & -8.41 & -1.16 & 7.25 & 5.59 & 325.339 & 0.33 & 327.70 & 1.50 & 0 & 4 \\
\hline G & -8.41 & -1.26 & 7.15 & 5.51 & 341.794 & 0.73 & 336.57 & 1.52 & 0 & 4 \\
\hline $\mathbf{H}$ & -8.41 & -1.26 & 7.15 & 5.57 & 341.794 & 0.73 & 336.64 & 1.52 & 0 & 4 \\
\hline I & -8.71 & -1.36 & 7.35 & 3.53 & 376.239 & 1.29 & 349.92 & 1.54 & 0 & 4 \\
\hline $\mathbf{J}$ & -8.31 & -0.76 & 7.55 & 7.85 & 363.457 & 1.83 & 395.39 & 1.59 & 0 & 4 \\
\hline $\mathbf{K}$ & -8.62 & -0.74 & 7.88 & 5.86 & 321.376 & 0.67 & 341.40 & 1.51 & 0 & 4 \\
\hline
\end{tabular}

Note $\mathrm{E}_{\mathrm{HOмо}}=$ Highest occupied molecular orbital energy; $\mathrm{E}_{\mathrm{LUMO}}=$ lowest unoccupied molecular orbital energy; BG= Band Gap: DM= Dipole Moment; MW= Molecular weight; Vol= Volume; HDB= Hydrogen bond donor; $\mathrm{HBA}=$ Hydrogen Bond Acceptor

3.2. Docking Studies on 2-(quinoline-4-yloxy) acetamide derivatives and alanine dehydrogenase to down-regulate M. tuberculosis.

The molecular docking simulation of the ligand-receptor complexes brought about nine conformations, and the conformation with the highest (in terms of Negative) is assumed to be the best. The binding affinity for each biochemical interaction was observed and reported accordingly (Table 3). The calculated binding affinity for the studied compounds was -6.5 $\mathrm{kcal} / \mathrm{mol},-7.1 \mathrm{kcal} / \mathrm{mol},-6.2 \mathrm{kcal} / \mathrm{mol},-7.7 \mathrm{kcal} / \mathrm{mol},-7.4 \mathrm{kcal} / \mathrm{mol},-6.7 \mathrm{kcal} / \mathrm{mol},-6.5$ $\mathrm{kcal} / \mathrm{mol},-6.8 \mathrm{kcal} / \mathrm{mol},-6.6 \mathrm{kcal} / \mathrm{mol},-7.0 \mathrm{kcal} / \mathrm{mol},-6.3 \mathrm{kcal} / \mathrm{mol}$ for compound $\mathbf{A}$ to $\mathbf{K}$ as shown in Table 3 and compound $\mathbf{D}$ with $-7.7 \mathrm{kcal} / \mathrm{mol}$ proved to be the best to inhibit alanine dehydrogenase thereby down-regulating $M$. tuberculosis than other studied compounds as well as the referenced drug. The ability of 2-((6-Methoxy-2-methylquinolin-4-yl)oxy)-1-(2methoxyphenyl)ethan-1-one (D) to inhibit alanine dehydrogenase could be attributed to the attached derivative $(\mathrm{R} 1=\mathrm{H} ; \mathrm{R} 2=4-\mathrm{MeO}-\mathrm{Ph})$ and the position at which they are attached.

The residues involved in each interaction were Ala179, Val239, Leu240, Leu130, Leu127, Pro242 for compound A; Gly125, Ala126, Leu240, Gly177, Ala179, Ser134, Leu130, Ala131 for compound B; His96, Asp270, Gln99, Lys10, Ala299 for compound C; His96, Leu130, Ala131, Ser134 for compound D; Ala137, Ser134, Leu130, Leu240, Lys75, Pro302, Phe94, Met133 for compound E; Leu240, Val239, Ala179, Gly177, Leu127, Pro242, Asp198 for compound F; Tyr147, His148, Tyr283 for compound G; Ala179, Gly177, Val239, Leu240, Pro242, Leu127, Leu130 for compound H; Tyr147, His148 for the compound I; Tyr147, His148, Gln143, Tyr283, Phe14 for compound J; Tyr283, Ser304, Leu140, Val144, His148, Tyr147 for compound K. In this work, the combination of interactions observed between compound $\mathbf{D}$ and 2 voe were Conventional Hydrogen Bond, Alkyl, Pi-Alkyl, Pi-Sigma. These proved to have enhanced its ability to bind well to the studied receptor than other studied compounds (Figure 1). 
Table 3. Interactions between 2-(quinoline-4-yloxy)acetamide derivatives and Alanine Dehydrogenase (PDB ID: 2voe)

\begin{tabular}{|c|c|c|c|}
\hline & $\begin{array}{l}\text { Binding Affinity } \\
(\text { kcal/mol })\end{array}$ & Residue Involved in the interaction & Types of Interaction \\
\hline A & -6.5 & Ala179, Val239, Leu240, Leu130, Leu127, Pro242 & $\begin{array}{c}\text { Conventional Hydrogen Bond, Pi-Alkyl, } \\
\text { Alkyl }\end{array}$ \\
\hline B & -7.1 & $\begin{array}{l}\text { Gly125, Ala126, Leu240, Gly177, Ala179, Ser134, } \\
\text { Leu130, Ala131 }\end{array}$ & $\begin{array}{l}\text { Conventional Hydrogen Bond, Amide-Pi } \\
\text { Stacked, Alkyl, Pi-Alkyl }\end{array}$ \\
\hline $\mathrm{C}$ & -6.2 & His96, Asp270, Gln99, Lys10, Ala299, & $\begin{array}{l}\text { Conventional Hydrogen Bond, Carbon } \\
\text { Hydrogen Bond, Pi-Anion, Pi-Donor } \\
\text { Hydrogen Bond, Pi-Sigma, Pi-Alkyl }\end{array}$ \\
\hline $\mathrm{D}$ & -7.7 & His96, Leu130, Ala131, Ser134 & $\begin{array}{l}\text { Conventional Hydrogen Bond, Alkyl, Pi- } \\
\text { Alkyl, Pi-Sigma }\end{array}$ \\
\hline $\mathrm{E}$ & -7.4 & $\begin{array}{l}\text { Ala137, Ser134, Leu130, Leu240, Lys75, Pro302, } \\
\text { Phe94, Met133 }\end{array}$ & $\begin{array}{l}\text { Unfavorable Acceptor-Acceptor, Pi-Cation, } \\
\text { Pi-Sigma, Pi-Pi T-shaped, Alkyl, Pi-Alkyl }\end{array}$ \\
\hline $\mathrm{F}$ & -6.7 & $\begin{array}{l}\text { Leu240, Val239, Ala179, Gly177, Leu127, } \\
\text { Pro242, Asp198 }\end{array}$ & $\begin{array}{l}\text { Carbon Hydrogen Bond, Halogen, Alkyl, Pi- } \\
\text { Alkyl, Pi-Sigma }\end{array}$ \\
\hline G & -6.5 & Tyr147, His148, Tyr283 & Conventional Hydrogen Bond, Pi-Alkyl \\
\hline $\mathrm{H}$ & -6.8 & $\begin{array}{c}\text { Ala179, Gly177, Val239, Leu240, Pro242, } \\
\text { Leu127, Leu130 }\end{array}$ & $\begin{array}{l}\text { Conventional Hydrogen Bond, Alkyl, Pi- } \\
\text { Alkyl, Pi-Sigma }\end{array}$ \\
\hline I & -6.6 & Tyr147, His148 & Conventional Hydrogen Bond, Pi-Pi Stacked \\
\hline $\mathrm{J}$ & -7.0 & Tyr147, His148, Gln143, Tyr283, Phe14 & $\begin{array}{l}\text { Conventional Hydrogen Bond, Carbon } \\
\text { Hydrogen Bond, Pi-Pi Stacked, Pi-Alkyl }\end{array}$ \\
\hline $\mathrm{K}$ & -6.3 & Tyr283, Ser304, Leu140, Val144, His148, Tyr147 & $\begin{array}{l}\text { Conventional Hydrogen Bond, Carbon } \\
\text { Hydrogen Bond, Pi-Pi Stacked, Alky }\end{array}$ \\
\hline $\mathrm{INH}$ & -5.3 & & \\
\hline
\end{tabular}

Note: INH denotes Isoniazid (Reference Drug)
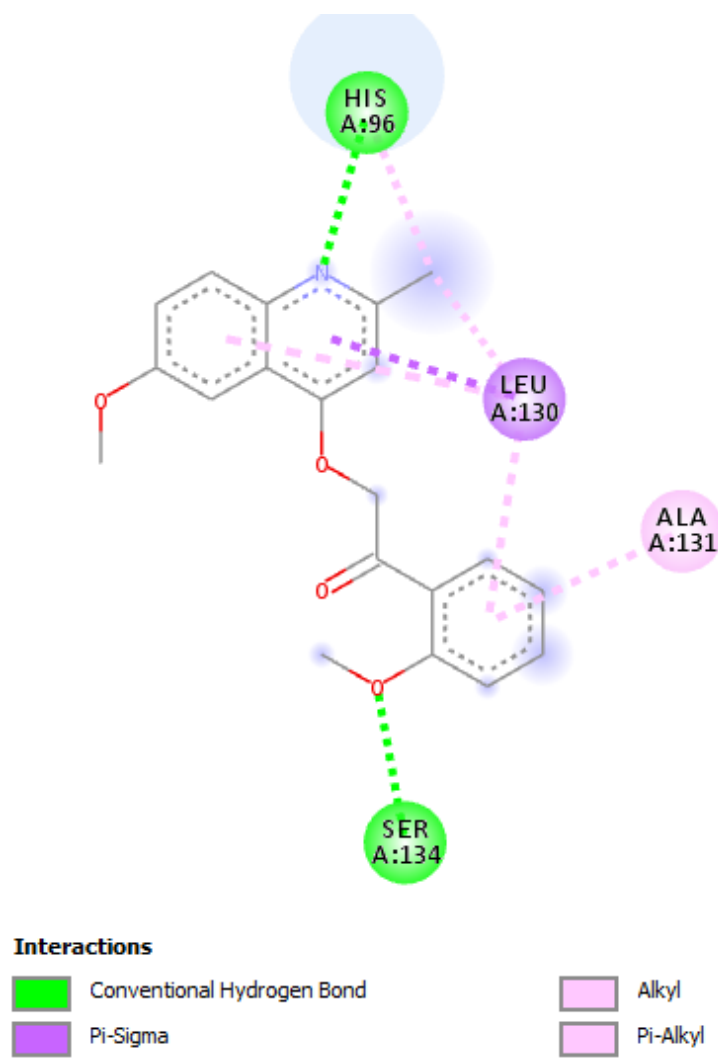

Figure 1. Bonded and non-bonded interactions of $\mathbf{D}$ against Alanine Dehydrogenase (PDB ID: 2voe).

\subsection{ADMET properties of studied selected compounds.}

The ADMET report for the selected compound D and the referenced drug (Isoniazid) are shown in Table 4. Absorption, distribution, metabolism, excretion, and toxicity for 
compound D with better binding affinity than other studied compounds were calculated using the admetSAR1 server. The compound with higher human intestinal absorption values is expected to have a higher ability to be absorbed well [28-32]. Therefore, the values obtained for human intestinal absorption (HIA) for selected compounds correlated with the standard (Isoniazid), proving that the selected compounds can be absorbed in the intestine. Also, a fair correlation was observed between compound $\mathbf{D}$ and Isoniazid for the blood-brain barrier. As shown in Table 4, the evaluation of predicted Cytochrome P450 showed that compound $\mathbf{D}$ and the standard are non-inhibitors of CYP450 2C9 Inhibitor and CYP450 2D6 Inhibitor. Still, the selected compounds and the reference drug are inhibitors of CYP450 1A2 Inhibitor. Also, compound D is an inhibitor of CYP450 2C19 Inhibitor and CYP450 3A4 Inhibitor. More so, both compounds D and Isoniazid (Standard) are non-carcinogenic agents and are not readily biodegradable, as displayed in Table 4.

\section{Conclusions}

In this work, eleven chemical compounds were investigated via the quantum chemical method, molecular docking, and ADEMT studies. The selected obtained descriptors (Log P, HBA, HBD and molecular weight) proved the ability of the studied compounds to have druglike properties. Molecular docking study was performed in order to identify the non-bonding interactions and calculated the binding affinity that exists between the eleven compounds and the Alanine Dehydrogenase. Compound D inhibited far better than the other studied ligands as well as the standard. ADMET properties of $\mathbf{D}$ proved that the predicted ADMET level was closer to the ADMET properties of the referenced drug (Isoniazid).

Table 4. ADMET properties of studied selected compounds.

\begin{tabular}{|c|c|c|c|c|}
\hline & \multicolumn{2}{|c|}{ Compound D } & \multicolumn{2}{|l|}{ Isoniazid } \\
\hline Mode & Result & Probability & Result & Probability \\
\hline Blood-Brain Barrier & $\mathrm{BBB}+$ & 0.9305 & $\mathrm{BBB}+$ & 0.9895 \\
\hline Human Intestinal Absorption & HIA+ & 0.9926 & HIA+ & 0.9892 \\
\hline Caco-2 Permeability & $\mathrm{Caco} 2+$ & 0.8120 & $\mathrm{Caco} 2+$ & 0.6959 \\
\hline P-glycoprotein Substrate & Non-substrate & 0.6121 & Non-substrate & 0.8315 \\
\hline \multirow[t]{2}{*}{ P-glycoprotein Inhibitor } & Inhibitor & 0.6095 & Non-inhibitor & 0.9778 \\
\hline & Non-inhibitor & 0.6715 & Non-inhibitor & 0.9960 \\
\hline $\begin{array}{c}\text { Renal Organic Cation } \\
\text { Transporter }\end{array}$ & Non-inhibitor & 0.7623 & Non-inhibitor & 0.9054 \\
\hline Subcellular localization & Mitochondria & 0.7309 & Mitochondria & 0.7026 \\
\hline CYP450 2C9 Substrate & Non-substrate & 0.8189 & Non-substrate & 0.9088 \\
\hline CYP450 2D6 Substrate & Non-substrate & 0.5716 & Non-substrate & 0.9116 \\
\hline CYP450 3A4 Substrate & Substrate & 0.6252 & Non-substrate & 0.7557 \\
\hline CYP450 1A2 Inhibitor & Inhibitor & 0.8975 & Inhibitor & 0.6482 \\
\hline CYP450 2C9 Inhibitor & Non-inhibitor & 0.7850 & Non-inhibitor & 0.9273 \\
\hline CYP450 2D6 Inhibitor & Non-inhibitor & 0.8230 & Non-inhibitor & 0.9443 \\
\hline CYP450 2C19 Inhibitor & Inhibitor & 0.7781 & Non-inhibitor & 0.9513 \\
\hline CYP450 3A4 Inhibitor & Inhibitor & 0.7722 & Non-inhibitor & 0.5111 \\
\hline CYP Inhibitory Promiscuity & $\begin{array}{l}\text { High CYP Inhibitory } \\
\text { Promiscuity } \\
\end{array}$ & 0.8074 & $\begin{array}{l}\text { Low CYP Inhibitory } \\
\text { Promiscuity }\end{array}$ & 0.9342 \\
\hline \multirow{2}{*}{$\begin{array}{c}\text { Human Ether-a-go-go-Related } \\
\text { Gene Inhibition }\end{array}$} & Weak inhibitor & 0.9603 & Weak inhibitor & 0.9872 \\
\hline & Non-inhibitor & 0.8508 & Non-inhibitor & 0.9586 \\
\hline AMES Toxicity & AMES toxic & 0.6654 & AMES toxic & 0.8557 \\
\hline Carcinogens & Non-carcinogens & 0.9470 & Non-carcinogens & 0.7514 \\
\hline Fish Toxicity & High FHMT & 0.6835 & Low FHMT & 0.9451 \\
\hline Tetrahymena Pyriformis Toxicity & High TPT & 0.9856 & Low TPT & 0.7464 \\
\hline Honey Bee Toxicity & High HBT & 0.6198 & Low HBT & 0.8399 \\
\hline Biodegradation & Not ready biodegradable & 0.8484 & Not ready biodegradable & 0.9810 \\
\hline
\end{tabular}




\section{Funding}

This research did not receive any specific grant from funding agencies in the public, commercial, or not-for-profit sectors.

\section{Acknowledgments}

We are grateful to the Department of Pure and Applied Chemistry, Osun State University, for the computational resources and Mrs. E.T. Oyebamiji as well as Miss Priscilla F. Oyebamiji for the assistance in the course of this study.

\section{Conflicts of Interest}

The authors declare that they have no known competing financial interests or personal relationships which have or could be perceived to have influenced the work reported in this article.

\section{References}

1. Law, C. T.; Camacho, F.; Garcia-Alles, L. F.;Gilleron, M.; Sarmiento, M. E.; Norazmi, M. N.; Acosta A.; Choong, Y. S. Interactions of domain antibody (dAbк11) with Mycobacterium tuberculosis Ac2SGL in complex with CD1b. Tuberculosis 2019, 114, 9-16.

2. Koul, A.; Arnoult, E.; Lounis, N.; Guillemont, J.; Andries, K. The challenge of new drug discovery for tuberculosis. Nature 2011, 469, 483-490, https://doi.org/10.1038/nature09657.

3. Kenia, P.; Anne, D.V.; Valnes, R-J.; Bruno, C.G.; Estevâ, o S.G.; Bruno, L.A.; Rogerio, V.T.; Laura, R.N.; Carla, D.B.; Davi, F.B.; Maria, M.C.; Luiz, A.B.; Diogenes, S.S.; and Pablo, M. 2-(Quinolin-4yloxy)acetamides Are Active against Drug-Susceptible and Drug-Resistant Mycobacterium tuberculosis Strains. ACS Med. Chem. Lett. 2016, 7, 235-239, https://doi.org/10.1021/acsmedchemlett.5b00324.

4. Kapron, B.; Luszczki, J.J.; Plaziska, A.; Siwek, A.; Karcz, T.; Grybos, A.; Bowak, G.; Makuch-Kocka, A.; Walczak, K.; Langner, E.; Szalast, K.; Marciniak, S.; Paczkowska, M.; Cielecka, J.; Ciesla, L.M.; Plech, T. Development of the 1,2,4-triazole-based anticonvulsant drug candidates acting on the voltage-gated sodium channels. Insights from in vivo, in vitro, and in silico studies. Eur J Pharm Sci 2019, 129, 42-57, https://doi.org/10.1016/j.ejps.2018.12.018.

5. Nara, S.; and Garlapati, A. Design, Synthesis and molecular docking study of hybrids of quinazolin-4(3H)one as anticancer agents. Ars Pharmaceutica 2018, 59, 121-131, https://doi.org/10.30827/ars.v59i3.7360.

6. Kraka, E. and Cremer, D. Computer Design of Anticancer Drugs. A New Enediyne Warhead. J. Am. Chem. Soc. 2000, 122, 8245, https://doi.org/10.1021/ja001017k.

7. Cohen, M.H. In Topics in Current Chemistry, Nalewajski RF, Ed.; Springer-Verlag: Heidelberg, Germany. 1996, 183, 143.

8. Nicholas, H.J.; Burckhalter, J.H. Camoquin Relatives. J. Am. Chem. Soc. 1952, 74, 271- 272, https://doi.org/10.1021/ja01121a521.

9. Awad, M.K. Semiempirical investigation of the inhibition efficiency of thiourea derivatives as corrosion inhibitors. J. Electroanal. Chem. 2004, 567, 219-225, https://doi.org/10.1016/j.jelechem.2003.12.028.

10. Parr, R.G.; Yang, W. Density functional approach to the frontier-electron theory of chemical reactivity. J. Am. Chem. Soc. 1984, 106, 4049, https://doi.org/10.1021/ja00326a036.

11. Pearson, R.G. Hard and Soft Acids and Bases. J. Am. Chem. Soc. 1963, 85, 3533, https://doi.org/10.1021/ja00905a001.

12. Oyebamiji, K.A.; Semire, B. Studies of 1, 4-Dihydropyridine Derivatives for Anti-Breast Cancer (MCF-7) Activities: Combinations of DFT-QSAR and Docking Methods. New York Science Journal 2016, 9. https://doi.org/10.7537/marsnys09061610.

13. Morris, G.M.; Lim-Wilby, M. Molecular docking. Methods Mol. Biol. 2008, 443, 365-382, https://doi.org/10.1007/978-1-59745-177-2_19. 
14. Sabitu, B.O.; Adamu, U.; Gideon, A.S.; Sani, U. Computer-aided drug design and in silico pharmacokinetics predictions of some potential antipsychotic agents. Sci. Afri. 2021, 12, e00734, https://doi.org/10.1016/j.sciaf.2021.e00734.

15. Segun, D.O.; Gideon, F.T.; Chunderika, M.; Bernard, O. $\operatorname{Ag}(\mathrm{I})$ symmetrical N, N'-diarylformamidine dithiocarbamate PPh3 complexes: Synthesis, structural characterization, quantum chemical calculations and in vitro biological studies. Inorganica Chim. Acta. https://doi.org/10.1016/j.ica.2021.120316.

16. Abdullahi, B.U.; Adamu, U.; Sani, U.; Gideon. A.S. QSAR and Docking Studies on Some Potential Anti-Cancer Agents to Predict their Efect on M14 Melanoma Cell Line. Chem. Afri. 2020, 3, 1009 - 1022 , https://doi.org/10.1007/s42250-020-00185-w.

17. Ana, F.B.; Josiane, D.P.; Bruno, L.A.; Fernanda, S.M.; Nathalia, S.; Kenia, P.; Raoní, S.R.; Alessandro, S.R.; Diana, M.; Miguel, V.; Cristiano, V.B.; Luiz, A.B.; Pablo, M. Design, synthesis, and evaluation of new 2(quinoline-4-yloxy)acetamide-based antituberculosis agents. European Journal of Medicinal Chemistry 2020, 192, 112179, https://doi.org/10.1016/j.ejmech.2020.112179.

18. Semire, B.; Oyebamiji, A.K. and Odunola, O.A. Tailoring of Energy Levels in (2Z)-2-cyano-2-[2-[(E)-2-[2[(E)-2-(p-tolyl)vinyl]thieno[3,2-b]thiophen-5-yl]vinyl]pyran-4-ylidene]acetic acid Derivatives via Conjugate Bridge and Fluorination of Acceptor units for Effective D- $\pi$-A Dye-Sensitized Solar Cells: DFT-TDDFT Approach. Res. Chem. Intermed 2017, 43, 1863-1879, https://doi.org/10.1007/s11164-016-2735-0.

19. Abdul-Hammed, M.; Semire, B.; Adegboyega S.A.; Oyebamiji A.K.; and Olowolafe T.A. Inhibition of Cyclooxygenase-2 and Thymidylate Synthase by Dietary Sphingomyelins: Insights from DFT and Molecular Docking Studie. Phys. Chem. Res 2020, 8, 296-310.

20. Oyebamiji, A.K.; Akintelu, S.A.; Odoemene, S.N.; Oyeneyin, O.E. and Semire, B. Theoretical Bioevaluation of 1,2,4-Thiadiazole-1,2,4-triazole Derivatives via Molecular Modelling Approach. Asian Journal of Organic \& Medicinal Chemistry 2021, 6 .

21. Oyebamiji, A.K..; and Semire, B. In-Silico Study on Anti-bacteria and Anti-fungal Activities of 3,4-Dihydropyrimidin-2(1H)-One Urea Derivatives. Chemistry Africa 2021, 4, 149-159, https://doi.org/10.1007/s42250-020-00202-y.

22. Oyebamiji, A.K.; Tolufashe, G.F.; Oyawoye, O.M.; Oyedepo, T.A. and Semire, B. Biological Activity of Selected Compounds from Annona muricata Seed as Antibreast Cancer Agents: Theoretical Study, Journal of Chemistry 2020, 2020, https://doi.org/10.1155/2020/6735232.

23. Oyebamiji, A.K.; Abdulsalami, I.O.; Semire B. Dataset on Insilico Approaches for 3,4-dihydropyrimidin2(1H)-one Urea Derivatives as Efficient Staphylococcus aureus Inhibitor. Data in Brief 2020, 32, 106195 , https://doi.org/10.1016/j.dib.2020.106195.

24. Adegoke, R.O.; Oyebamiji, A.K.; and Semire, B. Dataset on the DFT-QSAR, and docking approaches for anticancer activities of 1,2,3-triazole-pyrimidine derivatives against Human Esophageal Carcinoma (EC109). Data in Brief, 2020, 31, 105963, https://doi.org/10.1016/j.dib.2020.105963.

25. Oyebamiji, A.K.; Tolufashe, G.F.; Semire, B. Inhibition study on Anti-type 3 of $3 \alpha$-Hydroxysteroid Dehydrogenase Activity against 1,2,3-Triazolo[4,5-D]Pyrimidine Derivatives: Molecular modelling Approach. Scientific African 2020, 8, e00444, https://doi.org/10.1016/j.sciaf.2020.e00444.

26. Jie, S.; Feixiong, C.; You, X.; Weihua, L. and Yun, T. Estimation of ADME properties with substructure pattern recognition. Journal of Chemical Information and Modelling 2010, 50, 1034-1041, https://doi.org/10.1021/ci100104j.

27. Oyebamiji, A.K.; Tolufashe, G.F.; Oladipo, E.K.; Oyawoye, O.M.; Oyedepo, T.A.; Adeleke, B.B.; Akintelu, S.A.; and Semire, B. Computational Study on Selected Compounds in Garcinia Kola Seed as Potential Coronavirus Main Protease Inhibitors. Nat Sci 2020, 18, 78-85, https://doi.org/10.7537/marsnsj180920.10.

28. Mebarka, O.; Salah, B.; Khaled, L.; Ismail, D.; and Houmam, B. Molecular Docking Studies and ADMET Properties of New 1.2.3 Triazole Derivatives for Anti-Breast Cancer Activity. J. Bionanosci. 2018, 12, 26-36, https://doi.org/10.1166/jbns.2018.1505.

29. Oyebamiji, A.K.; Josiah, O.M.; Akintelu, S.A.; Adeoye, M.D.; Sabitu, B.O.; Latona, D.F.; Esan, A.O.; Soetan, E.A.; Semire, B. Dataset on Insightful Bio-Evaluation of 2-(quinoline-4-yloxy)acetamide Analogues as Potential Anti-Mycobacterium tuberculosis Catalase-Peroxidase Agents Via In silico Mechanisms. Data in Brief 2021, 38, 107441, https://doi.org/10.1016/j.dib.2021.107441.

30. Oyebamiji, A.K.; Akintelu A.S.; Mutiu, O.A.; Adeosun I.J.; Kaka M.O.; Olotu, T.M.; Soetan, A.E.; Adelowo, J.M.; Semire, B. In-Silico Study on Anti-cancer Activity of Selected Alkaloids from Catharanthus roseus. Trop J Nat Prod Res 2021, 5, 1315-1322, https://doi.org/10.26538/tjnpr/v5i7.25. 
31. Oyebamiji, A.K.; Akintelu, S.A.; Amao, O.P.; Kaka, M.O.; Morakinyo, A.E.; Amao, F.A.; Semire, B. Dataset on Theoretical Bio-Evaluation of 1,2,4-Thiadiazole-1,2,4-Triazole Analogues against Epidermal Growth Factor Receptor Kinase down Regulating Human Lung Cancer. Data in Brief 2021, 37, 107234, https://doi.org/10.1016/j.dib.2021.107234.

32. Oyebamiji, A.K, Mutiu, O.A.; Amao, F.A.; Oyawoye, O.M.; Oyedepo, T.A.; Adeleke, B.B.; Semire, B. Dataset on in-silico investigation on triazole derivatives via molecular modelling approach: A potential glioblastoma inhibitors. Data in Brief 2021, 34, 106703, https://doi.org/10.1016/j.dib.2020.106703. 